Manuscript accepted in Sustainability Science

The final publication is available at Springer via via http://dx.doi.org/10.1007/s11625-018-0610-1

\title{
Collaborative lessons towards marine sustainability - a long term collective engagement
}

Yorgos Stratoudakis ${ }^{1}$, Helena Farrall ${ }^{2}$ and Lia Vasconcelos ${ }^{3}$

1: IPMA - Rua Alfredo Magalhães Ramalho 6, Lisboa 1449-006, Portugal - yorgos@ipma.pt

2: Consultant - cahsystems@gmail.com

3: MARE (Marine and Environmental Sciences Centre), FCT-NOVA, 2829-516 Caparica, Portugal$\underline{\text { tvv@fct.unl.pt }}$

Corresponding author: Yorgos Stratoudakis (fax: +351 213015948; phone: +351 213027132) 
ABSTRACT: Collective engagement and inclusiveness have been in growing demand particularly within the context of managing natural resources. Here, a natural and a social scientist report on a case that the two have participated over the past decade, supported by a transdisciplinary evaluation framework. With the aid of a boundary scientist external to the process, analysis focuses on the delivery and update of spatial regulation and fishery management rules in a Marine Protected Area (Marine Park professor Luíz Saldanha) in Arrábida, Portugal, the temporal dynamics in key elements of collaboration and the building up of social, intellectual and political capital in the system. Long-term collective engagement showed that the emergence of key actors and the progression towards an outcome-driven agenda might have the downside to partially demobilize less active members. Further, the increased legitimacy of group action provided by institutional recognition may diminish adaptive capacity and group resilience. Nevertheless, negotiated group proposals to alter the bundles of fishing rights in the system and shaping of boundary objects with relevance to marine sustainability demonstrate that collective action by a community of practice can operate for long periods and deliver more than a compilation of individual wish-lists or noncommittal declarations.

Keywords: Collaborative governance; Marine Protected Area; Transdisciplinarity; Evaluation Framework; SW Portugal. 


\section{INTRODUCTION}

Management of common-pool resources poses a challenge to both natural and social scientists, given high demand for consumption and complex institutional arrangements to organize extraction (Dietz et al., 2003; Bodin, 2017). This becomes even more challenging in highly humanized landscapes, due to a more intense pressure on resources and a greater diversity of stakeholders that feel the need to be given a voice. These multi-stakeholder complex contexts in social-ecological systems (Edwards and Steins, 1998) raise the need for new tools for intervention. Some of these can be learned either professionally or intuitively (Bennett et al., 2017; Roos, 2017), but others are built up with experience and through "hands-on" exploration (Reed, 2008; Stratoudakis et al., 2015a; Marshall et al., 2017). Natural scientists are equipped to deal with resource dynamics, however they, quite often, were not trained to face stakeholder engagement and the need to bring them to the table of negotiation (Boschetti et al., 2016). Social scientists have been trained to handle engagement and conflict situations through professional facilitation (Bennett et al., 2017), though with limited (or no) understanding of the biological and ecological processes at play in the natural component of the system. This complementarity in skills has been traditionally overlooked by non-overlapping arrangements, but should go hand in hand to collectively shape thoughtful action when searching to introduce practical wisdom in sustainability governance (Roos, 2017). Thus, sustainability can be addressed twofold: the collaborative process and the natural resource system.

Marine Protected Areas (MPAs) are usually created where environmental value is high (in terms of biodiversity, habitats and ecosystem structure and function) and can be better protected or enhanced by spatial management measures (e.g. Batista et al., 2014). In coastal areas, MPA delimitation and implementation will inevitably interfere with pre-existing fishing activity: nature 
conservation within a MPA, in order to be effective, will need to curtail exploitation of resources in comparison with fishing effort in neighbouring areas (Horta e Costa et al., 2016). Nevertheless, MPA success towards marine sustainability will depend to a large extend on the capacity to negotiate and accept change, to contain conflicts and avoid solutions considered unjust by local communities (Bennett et al., 2015). Reduction of fishing effort in a MPA implies modification in the property rights held by users, by the introduction of more restrictive operational rules (i.e. generally agreed-upon and enforced prescriptions that require, forbid, or permit specific actions for more than a single individual - Schlager and Ostrom, 1992). Change in the operational rules are driven by collective-choice actions, themselves undertaken within a specific set of collectivechoice rules determining who may participate in changing operational rules and the level of agreement required for their change (Schlager and Ostrom, 1992; Edwards and Steins, 1998). The definition and modification of the rules that determine these bundles of rights is specific to the governance system of each MPA and will influence the effectiveness of MPA management in maintaining or improving marine environmental values (Horta e Costa et al., 2016) and the capacity to contain the level of associated tensions (Bennett et al., 2015).

While natural scientists are more focused in generating good tangible outcomes (e.g. rules, actions or strategies to be implemented and achieve desirable states of nature), social scientists focus mainly, through a process of dialogue, to produce intangible outcomes (e.g. trust, commitment) that emancipate stakeholders and assure continuity of the process. Although interactions between social and natural scientists are rapidly increasing, and often include wider partnerships and stakeholder collaborations to face sustainability challenges (Spangenberg, 2011; Holzer et al., 2018), reflection on the identification, meaning and success of such collaborative processes based on dialogue and negotiation are still limited. In particular, the co-production of knowledge that transcends disciplinary, academic and epistemic boundaries is still at its early days and faces both 
theoretical challenges and practical tensions (Scholz and Steiner, 2015a, b; Thompson et al., 2017), while the outcomes of collaboration and their evaluation may vary significantly depending on the theoretical angle (Gray and Wood, 1991).

The present case study focuses on a process of collaborative governance evolving in the Marine Park professor Luiz Saldanha (PMLS, SW Portugal) since 2008. The original aim of this collective engagement was to overcome the conflict and mistrust associated to the MPA designation in 1998 and regulation in 2005 (Carneiro, 2011; Vasconcelos et al., 2012), through the creation of a local "agora" for the co-production of knowledge among academic and non-academic communities (Pohl et al., 2010). Two researchers that participated in this process as the facilitator of a multiactor situation and as an intermediary in the co-production of knowledge respectively, act in the present study as reflective scientists (Pohl et al., 2010; Wittmayer and Schapke, 2014). With the aid of a boundary scientist external to the process, they report on the content of group discussions and its consequences for MPA management (Stratoudakis et al., 2015b-d; Batista et al., 2015) and on the evolution of the collaborative process and its wider tangible and intangible outcomes (Innes and Booher, 1999; Vasconcelos et al., 2012). The overall reflection takes in consideration "systematic institutional design" (Healey, 1997), i.e., the introduction of new rules and roles, while identifying the building up of an effective community of practice - "groups of people who share a concern or a passion for something they do and learn how to do better as they interact regularly" (Lave and Wenger, 1991) as a benchmark of success.

\section{CONCEPTUAL FRAMEWORK}

\section{THE DEMAND FOR COLLABORATIVE PROCESSES}

With the 1990s deliberative turn, the theory of democracy moved from being an aggregation of preferences to become a "democratic control through communication that encourages reflection 
upon preferences without coercion" (Dryzek, 2000). The idea is not to create more government, but to operate in a network form of organization, playing a crucial role in bringing contestation of discourses into the open. A way to contribute to this is through the creation and structuring of forums to debate ideas and allow for interaction (Fung and Wright, 2001). This is of utmost importance as we live in a "no one in charge", "shared power world", where "institutions and organizations have to share objectives, activities, resources and power, or authority to make collective gains and minimize losses" (Bryson and Crosby, 1992). Moreover, in the areas of policy and management the problems are frequently of high complexity, what Rittel and Weber (1973) called "wicked".

Socio-ecological dilemmas cannot be successfully addressed without some participation nor can they be dominated by the participatory process. Literature in citizen participation is inconclusive about how this looks in practice, and collects little consensus about what exactly is supposed to accomplish (Day, 1997). Many specialists, frustrated with inadequately conducted participatory processes, have considered participation a generator of societal conflicts, rather than seeing it as part of the solution. The failure to integrate concerns and interests of those affected by public decisions, contributes frequently to feed the conflict and radicalize positions. These problems have a multiplicity of solutions depending on the definition adopted for them, thus, the problem definition itself requires some process of consensus building. One of the aspects frequently ignored in the decision-making process in complex contexts is that it is not exclusively technical, but includes several political options and value judgment that, when not timely taken into account, generate later a lot of controversy (Lake, 1987). Insufficient interaction to settle disputes in complex contexts, call for collaborative processes allowing for interactive, structured and facilitated meeting, where stakeholder participation is inclusive, creative, and based on true dialogue (Ansell and Gash, 2008). 
There are a variety of ways to structure and conduct participation, with no unique pattern or recipe. A series of successful case studies inspired these collaborative methodologies and have dictated the main rules (Innes and Booher, 2004; Vasconcelos, 2005; Reed, 2008). In these new formats, collaborative methodologies have to be positioned more and more at the earlier stages of the process. These collaborative methods based on the dialogue among parts, encourage the effective interactive involvement of stakeholders, assuring that stakeholders are heard and that their interests and concerns are integrated in the process. They also place new interrogations to the role of scientists with responsibility in the formulation of advice for public environmental policies and management (Jacobsen et al., 2012; Linke and Bruckmeier, 2015; Linke and Jentoft, 2016; Stange et al., 2016; Marshall et al., 2017).

\section{TRANSDISCIPLINARITY AND SUSTAINABILITY}

Transdisciplinary approaches are increasingly accepted by the public and scientists alike as the best way to address sustainability problems (Pohl et al., 2010; Lang et al., 2012). The concept of transdisciplinarity can be placed along a gradient between two extremes (Scholz and Steiner, 2015a): at one end, a facilitated process of mutual learning between science and society, relating a (multi)-disciplinary research process and a (multi)-stakeholder discourse for developing socially robust orientations on a specific, societally relevant, issue (Mode-2 transdisciplinarity); at the other end, a process focused on the merging of scientific ideas and methods in a consistent manner and without boundaries, beyond the interdisciplinarity of neighbouring scientific domains (Mode-1 transdisciplinarity). In the present study, two transdisciplinary approaches are intermingled: the first one, inherent to the decade of collaboration in the PMLS, is closer to Mode2 ideal type, while the researchers' joint reflection in reporting on the outcomes of this decade gets closer to Mode-1. 
Transdisciplinary processes generate new knowledge and thus go hand in hand with intellectual capital. However, these processes are only sustainable if they concomitantly produce other types of capital. By sustainability of a collaborative process the authors mean the capacity of the collaborative group to maintain a continuous dynamic of definition and approach to problems. This is particularly relevant for MPA governance, where an agora space may need to emerge at any moment to handle conflict or rule modifications. Implementing transdisciplinary strategies in natural resources' sustainable management involves continuous learning, which in turn requires outcome monitoring and evaluation. In a transdisciplinary collaborative process, action and structure are interrelated as the interactions among agents dictate the emergence of structures that, in turn, constrain future behaviour of agents (Edwards and Steins, 1998). In addition, because sustainability is context-dependent and historically contingent, collaborative dynamics are sensitive to the initial architecture of ecological, social, intellectual, and political conditions and essentially non-linear: adaptive capacity and resilience in face of changing conditions vary over time (Scholz and Steiner, 2015a). This wide perspective needs to consider all types of process outcomes, as some of them are key for the sustainability of the collaborative process.

\section{COLLABORATIVE PROCESS OUTCOMES}

The outcome of a collaborative process produces three types of capital - social, intellectual and political - that encompass tangible and intangible outcomes (Innes and Booher, 1999). These authors argue that participants in collaborative processes build social capital through strengthening relationships (personal and professional) and trust to contribute to genuine communication and joint problem solving. This diminishes hostility, promotes knowledge sharing and predisposes the participants to negotiate conflicting issues. In most such processes stakeholders also build intellectual capital, meaning knowledge in the forms of mutual 
understanding of each-others' interests, shared definitions of the problem, and agreement on data, models, projections, or other quantitative or scientific descriptions of issues. Intellectual capital plays a crucial role in equipping stakeholders with the adequate tools for action coordination and conflict resolution. Stakeholders can also develop political capital. With it they begin working together outside the process to influence public action, something they were not able to do previously as individuals (Innes and Booher, 1999).

The concept of sustainable collaboration implies the creation of public value (Thomson et al., 2008) which is linked to commitment. This is key to the continuity of a collaborative process and to keep it going beyond its original starting point. In terms of materiality, outcomes can be classified as tangible or intangible. Intangible outcomes are effects or results that emerge out of the process and in general cannot be formalized as a delivery - they are elements that are important for the success of the process but harder to identify and report (Thomson et al., 2008), although some can be formalized (e.g., a training period formalized by a certificate issued to the trainee). According to Huxham (1996) intangible outcomes are key for "long term substantive societal changes". Tangible outcomes are results that can have a tangible form, also called products (e.g., actions, documents) and are widely used by decision makers. Between the two can be placed boundary objects that emerge in the agora and serve to mobilize, share, transfer and translate mixed-actor knowledge and thus facilitate common understanding and knowledge co-production (Stange et al., 2016). In these circumstances, identifying consistent evaluation criteria, guidelines and frameworks is a difficult but necessary task (e.g. Regeer et al., 2009; Lang et al. 2012; Zscheischler \& Rogga, 2015; Holzer et al., 2018). The assessment of transdisciplinary processes requires innovative forms of quantitative and qualitative appraisal and validation is an assertion generally accepted among the scientific community. Scholz and Steiner (2015b) defend the evaluation of transdisciplinarity based 
on a clear theoretical framework that allows "to properly acknowledge the fundamental processes of acquiring, processing, and integrating knowledge both in Mode 1 and Mode 2 transdisciplinarity". For those authors, the validation of newly produced outcomes (knowledge, decisions, actions, and impacts on science and society) must transcend "face validation"; also, the quality of the process is a necessary prerequisite for the overall quality of a project, although they consider both the quality of the Mode 2 process and of project outcomes.

Holzer et al. (2018) consider that there are important caveats in the evaluation of a short-term effort that will only generate long-term social change or when attempting to group discrete results on a complex and dynamic research network. Zscheischler and Rogga (2015) note that authors tend to highlight and report on successful collaborations, feasible outputs, and recently assimilated knowledge when evaluating transdisciplinary processes; few studies reflect upon the setbacks, and the process of learning through failure that occurs during the process. Bigham et al. (2003) calls attention to the need to view evaluation of a collaborative process as part of an extended systematic learning process that looks for patterns of outcomes across cases over time. To understand the collaborative processes' potential a new mind-set is required to assess the changes in course and to help the community to attain new levels of social and environmental achievements (Innes and Booher, 1999). The latter offer an evaluative framework for collaborative processes that provided the inspiration to propose this tripartite view focusing specifically in the three capitals - social, intellectual and political - to structure and analyse more deeply a continuous ongoing process and extract lessons from the reflection along the three phases of a decade of an ongoing collective engagement process, identifying the outcomes - tangible and intangible - generated from the collaborative processes. Furthermore, it analyses three areas as suggested by Gray and Wood's (1991, in Thomson et al., 2008: antecedents to collaboration, the process of collaboration itself, and the outcomes of that process). 


\section{METHODS}

The first section presents the three steps of the transdisciplinary evaluation framework implemented to the PMLS collective engagement case study. The second section presents the study system and its evolution since legal designation as an MPA in 1998. The third section describes the period of engagement that was initiated by a research project in 2008 and is still evolving. To facilitate analysis and interpretation of case study dynamics, the period of engagement is divided in three successive phases of stakeholder interactions.

\section{EVALUATION FRAMEWORK}

To reflect on the collaborative process in terms of sustainability, a three step approach is followed:

STEP 1 - Reflecting over the Sustainable Outcomes for the MPA

The first step is to reflect on outcomes with direct implications to sustainability of the MPA. These are considered to be proposals created by the group to modify fishing rules and reported in the first results section. These outcomes are evaluated according to their potential consequence in fishing effort within the PMLS (reduction, no change, increase) and on their influence in the effectiveness of MPA regulation according to the framework of Horta e Costa et al. (2016).

STEP 2 - Reflecting over the Collaborative Process

Process outcomes presented in the second results section and are evaluated using a structure (Table 1) developed taking into account ten elements of participation considered key to a collaborative process based on Vasconcelos (2005), and using trend criteria to qualitatively assess the process evolution in three periods of time. 
STEP 3 - Joint Reflection of the Overall Outcomes

The third part of the results section accounts for tangible and intangible outcomes of the PMLS case study for the three types of capital - Intellectual, Social and Political. Main points are raised by both scientists, mediated by the third boundary scientist that did not take part in PMLS engagement, providing the basis for an overall reflection on the long-range continuous process over the collaborative process in the three time periods.

THE SOCIAL-ECOLOGICAL SYSTEM: THE MARINE PARK PROF. LUIZ SALDANHA

The Natural Park of Arrábida (Parque Natural de Arrábida - PNA) was created in 1976 to protect one of the most important green areas within the metropolitan region of Lisboa-Setúbal from increasing anthropogenic pressure and degradation. Although the marine zone of Arrábida was also considered to deserve conservation attention, the protected area designation in 1976 only included a terrestrial component of approximately $120 \mathrm{~km}^{2}$. The Marine Park was legally designated in 1998 as the seaward expansion of PNA in a coastal area across 38 km, covering 53 km² of rocky, sandy and muddy bottom habitats (Cunha et al., 2014; Henriques et al., 2015). In 2005 was published legislation to define the spatial plan of the PMLS and to regulate all human activities within the PNA (including PMLS), after 2-3 years of public consultation, external review and heated stakeholder protests (Carneiro, 2011). This plan established the zoning of PMLS into an area of total protection (marine reserve without regular human activity, almost $8 \%$ of total area), 4 partial protection areas (39\% of total, with highly regulated human activity) and remaining complementary buffer areas.

These two legislative acts brought restrictions to fishing within the PMLS beyond those generically applied in the continental shelf of mainland Portugal (in 1998 the use of bivalve dredgers and the hand-pick of bivalves with diving equipment was prohibited across the PMLS; for changes in 2005 
see results and Table 2). These rules created tension and conflicts with the PMLS management authority (ICNF), not only for those excluded from the PMLS, but also for those that retained fishing access rights under stricter conditions of operation (Stratoudakis et al., 2015b).

\section{COLLECTIVE ENGAGEMENT: A CONTINUUM IN THREE PHASES}

The case study started in 2008 and can be divided in three phases: Initially, the MARGov project was developed between 2008 and 2011 aiming to engage stakeholders dissatisfied with early public consultations and critical of PMLS implementation (Carneiro, 2011) and mobilize them in co-production of knowledge (Vasconcelos et al., 2012; Vasconcelos et al., 2015). In a second phase, relevant MARGov actors emerged out of the previous phase and requested to continue the debate on PMLS regulation through the Post-MARGov Group that was informally established and functioned between 2012 and 2014. In the third phase, from the end of 2014 onwards, the PNA Strategic Council invited the post-MARGov Group to become the Group of the Sea, a working group of the Council with a mandate on marine issues. A common thread of the three phases has been the aim of the same facilitation team to build on small gains that deepen trust, commitment and shared understanding to reach, if nothing else, some degree of consensus among stakeholders (Answell and Gash, 2008).

1) MARGov (2008-2011): Engagement and Mobilization of Stakeholders

The main challenge for MARGov was to make the most out of the existing PMLS conflict, framing it to build-up a collective discourse for the MPA. For that the central idea was to open up an agora space for stakeholders to safely express their disagreements and discuss the conflicting issues. One of the main tasks was to overcome myths that were created by the radicalization of positions due to the controversy related to the introduction of zonation in the MPA and the creation of exclusion areas (Carneiro, 2011; Vasconcelos et al., 2012; Vasconcelos et al., 2015) - the project 
team believed that the fact that stakeholders had something important at stake made them more prone to get engaged in the process and provide a more substantiated departure point enriching the project. Several social objectives provided the background for the team operation, namely to set the ground for an open and genuine dialogue where all the parts were heard, assure the articulation of different types of knowledge, contribute to the empowerment of the stakeholders and promote the creation of change agents. Apart from the social objectives, a set of instrumental objectives supported the project, such as develop collaborative solutions, create joint articulated proposals, develop consensual actions, and build a model of co-management for the MPA (Vasconcelos et al., 2015).

Though the project officially started in 2008 , the collaborative, professionally facilitated, process was initiated in October 2009. The first step was to empower and amplify the voice of the less vocal stakeholder - the local artisanal fishermen. Once this was done, regular Inclusive Open Forums were created to engage the diversity of PMLS stakeholders. Until the end of the project in 2011, stakeholders met regularly in this setting and debated issues from a jointly built collective agenda, co-constructing a collective dialogue. During this period people got to know each other's points of view, exchange ideas and perspectives, learn from the crossing of different types of knowledge and build together a proposal for a model of co-management for PMLS. This contributed along the way to empower the stakeholders and build a collective discourse essential for the follow up.

2) Post-MARGov (2012-2014): Structured Multi-actor Situation (Informal)

The final stages of MARGov coincided with the onset of another international project (MAIA, INTERREG - EU funding) that included PMLS as a Portuguese case study. Although MAIA mainly aimed at the coordination of MPA managers among neighbouring countries in the European 
Atlantic coast, temporal overlap permitted the continuation of the process in collective engagement initiated by MARGov. At a MAIA conference on MPA management, held in Coruña, Spain during June 2012, a set of key PMLS stakeholders - the nucleus of the MARGov Open Forum participants - launched the seed for the follow-up to MARGov, the post-MARGov. The invitations for participation in this international event were based on the experience of MARGov, seeking a plurality of perspectives and sector representativeness.

The MARGov coordination team structured the new collaborative process and coordinated and facilitated the meetings with this group (10 to 13 persons). The first meeting of the Post-MARGov was held in July 2012 to set up collectively the way work would develop in this new phase, as well as defining the role to be assumed by the group. From this, followed a series of meetings, held in Sesimbra with participation of a set of entities: Fisher Association (AAPCS, 2 persons: president and secretary); Institute of Nature Conservation (ICNF, 1 person); Fisheries Administration (DGRM, 1 person); Fisheries Research Institute (IPMA, 1 person); NGO (LPN, 1 person); Municipality (Sesimbra, 2 for fishing 1 for tourism); Association of Tourism Promoters (APECATE, 1 person); Local Dwellers Association (Clube Arrabida, 1 person).

Despite the association with the project MAIA and the logistic support by the Municipality of Sesimbra, the post-MARGov phase occurred without funding and no other mandate than the will of its members to continue the engagement, under the coordination and facilitation of the MARGov team. Initially the agenda was revisited and reformulated, and the group met aiming to achieve consensus for the revision in several points of the PMLS regulation. For that, the group chose the format and way to operate. The overall decision was to keep the group small and each time there was a need to debate issues that needed other stakeholders these would be invited for 
specific meetings (this happened twice in dedicated meetings with representatives of recreational fishers and of purse seine fishing vessels of Sesimbra).

3) Group of the Sea (2014-2017): Consultant Group with Legitimacy (Mandate)

During the spring of 2014, the post-MARGov informal group sent a letter to the Strategic Council of PNA to inform on the course of action taken since 2012 and recommend a closer interaction or integration within the formal MPA consultation structure. During the meeting of the Council in June 2014, the results of project MAIA were presented and the activity of post-MARGov discussed. By the end of 2014, post-MARGov was invited to become formally the Group of the Sea of the Council, with a mandate on issues related to PMLS. During this new phase group work followed the same dynamics and rules, although some institutional partners reconsidered the person and role of their representative. Further, although a few stakeholders had incompatible agendas, most group members were present in practically all meetings. More recently, an evaluation of the PNA regulation was performed by an independent team and the group had an opportunity to discuss it and give its own contributions to the MPA Council and its management authority.

More than 10 years after implementation of the PMLS plan and regulation, some positive ecological signs can be detected resulting from MPA management (Cunha et al., 2014; Abecassis et al., 2014; Batista et al., 2015) and wider perceptions of stakeholders are positive with respect to ecological and governance aspects (Stratoudakis et al., 2015c). However, perceptions are mixed with respect to the socio-economic effects of PMLS, being negative or neutral for fisheries (considering that the increase in spatial restrictions have not resulted in increase of yield for the main target species, but see also Batista et al., 2015) and positive for other economic activities (considering that PMLS has increased visitation and business opportunities for leisure activities thus increasing local employment and revenue -Stratoudakis et al., 2015 b and c). An external 
assessment of the PNA regulation was concluded in 2016 and made publicly available

(http://www.icnf.pt/portal/naturaclas/ordgest/poap/avaliacao-po-pnsc-pna). In 2017, the report was discussed within the Strategic Council of PNA, an official entity in the governance of the protected area that includes representatives of local and national institutions and reports to ICNF.

\section{RESULTS}

The following sections correspond to the three steps of the evaluation framework described above to identify process attributes and engagement outcomes, both tangible and intangible.

TOWARDS A SUSTAINABLE MPA

Operational and collective-choice rules for fishing in the PMLS changed significantly with the implementation of spatial regulation; Table 2 shows these changes and lists proposals discussed within the Group of the Sea in the first semester of 2017 to modify PMLS rules that created most conflict with the local fishing community. Of the 13 proposals put forward, five reached collective agreement, three with annotated reserves from members whose starting position had some substantial departure. The remaining proposals ranged from issues where partial agreement was reached to proposals that were clearly antagonistic. Four proposals were enriched by positions from the whole group on topics related to the potential interaction of fishing with tourism within PMLS (boundary object with interest for future exploration), while the remaining were dealt with by the sub-group with fisheries interests.

Table 2 also indicates that there are approximately equal numbers of proposals with positive or neutral/positive, neutral and negative or neutral/negative anticipated effect on PMLS sustainability in terms of fishing effort and MPA management effectiveness. Nevertheless, the five 
proposals that reached agreement are either neutral or positive. Of the proposals that did not reach agreement, the rule for the renewal of fishing licences in the PMLS received antagonistic proposals and constituted a topic that concentrated lengthy discussions and heated arguments, thus forming another boundary object to deserve future attention. Finally, beyond the proposals developed exclusively by the group and presented above, collective engagement in this decade provided other opportunities to address MPA sustainability issues among group members, some already resolved (e.g. granted license to fish red-mullets with smaller-mesh nets, refused licence to fish shrimps with traps) and others not (e.g. excess of octopus pots in the PMLS).

\section{COLLABORATIVE PROCESS: CHARACTERISTICS AND DYNAMICS}

Table 3 lists the elements of the collaborative process and describes their trend across the three phases of collective engagement. All elements evolved positively along time, except for:

- Professional Facilitator maintained the neutrality along the decade, following-up MARGov which was specifically designed by a professional facilitator independent team to structure and conduct the participatory process, to address the conflict and build a collective discourse;

- Actors Involvement intensified from MARGov to post-MARGOV, as participants of the latter were those that during MARGov had frequent and substantial contributions, willingness to engage in dialogue and were most representative of group positions. During the third phase, the formal mandate changed the equilibrium between personal action and institutional representation due to the need to negotiate in a space that privileged joint deliberation to build a group position open to public scrutiny. In addition, Issue Approach and Problem Translation was more successful in fisheries topics, leading to some disengagement of stakeholders with other interests; 
- Information Mode was influenced by Actors Involvement, with a distinct trend between fisheries and other topics. In fisheries, the flux of information increased throughout leading to a community of practice, where information specific to the clarification of doubts with respect to the assessment of the PMLS regulation was thoroughly debated and used to consolidate group positions. However, some of the members least present in meetings recurred to an intensive use of email to communicate information and positions to the group, with a resulting loss in the deliberative value of such information.

- Process Dynamics changed over the decade as a result of the increasing capacity to internalize and focus agenda definition and a parallel reduction of the capacity to adjust to contingency: in the early phase, the timing and consequences of a controversial meeting led to a temporary loss of momentum and required the rescheduling of operations, while in the second phase attempts to increase group autonomy with respect to the facilitating team were tried but with limited success, rapidly returning to the facilitated group format. This was more difficult to negotiate in the third phase, when external events (municipal elections and resulting appropriation of MPA problems by pre-electorate campaign party politics) and internal circumstances (partial disengagement of some members) created a temporary stalemate in the publication of a joint report.

\section{PROCESS CAPITAL BUILDING}

Table 4 summarizes the intellectual, social and political capital built during the three phases of collective engagement in the PMLS. The first period was marked by the building up of, mostly, social and intellectual capital. The social capital was revealed in ties and respect created among stakeholders and the intellectual in greater knowledge of diverse aspects, including some approximation in the definition of ecosystem value and function. Moreover, the empowerment of 
the less vocal stakeholders was evident since they became an active part in the meetings. The second phase contributed to the consolidation of intellectual capital (on legislation of issues under discussion, ecosystem functioning, etc.) reinforced the social capital of the group and their wider recognition by ICNF and its Strategic Council, gradually increasing the political capital. During the third phase, the political, social and intellectual capital was reinforced and the group became a true community of practice, able to debate and come to a closure in issues of interest.

In terms of intellectual capital, steady but slow progress has been made along the decade in the production of relevant information and its collective processing towards social learning within a community of practice. Part of the creation of new information related to PMLS was internalized along this period, with individual members of the group taking initiatives to set, fund and communicate new research or to produce scientific outputs related to stakeholder perceptions. More difficult has been group interaction with PMLS-related scientific information produced by academic teams not present in the group. Although PMLS science communication events are now regularly organized and well participated, collective processing of information is still limited and assimilation remains poor.

In terms of social capital, there is also an overall gain across the decade, but with periods of slow gain disrupted by short periods of rapid loss, often related to external events generating instability (e.g. municipal elections). Empowerment of individuals, institutions and sectors (binding capital) has been actively sought by MARGov but continued to be stimulated in later phases by interactions and networking promoted by group dynamics (bridging capital). For example, the interaction between a NGO and the fisher association for the promotion of a fish basket to the market led to stronger ties both within the fishing community and across organizations. Similarly, the understanding, and progressive assimilation and eventual internalization of engagement rules 
permitted the build-up of trust, both individual and institutional. The importance of face to face meetings and regular participation was critical in this process, with events in 2017 demonstrating that absence from meetings and reduction of involvement can affect the process and reduce the overall social capital available in the system, despite the strengthening of ties among those engaged.

The combination of gains in production and processing of relevant information, group member trust and capacity to work together, have contributed to the setting of a collective agenda and the production of novel collaborative solutions, both indicative of the achievements of a community of practice. Nevertheless, the incapacity of the group to act without the coordination of the facilitation team and the recent challenge by less participant members demonstrate that this community is still fragile and can easily reverse. Finally, in terms of political capital, there is an objective gain along the decade simply by considering the semi-institutionalization of the group within the Strategic Council of PNA. There is no doubt that as the group grew in maturity and got more consolidated it also became more recognized and respected, amplifying its voice in the decision making arena. This also created or increased the value in group membership, with additional stakeholders requesting access and willing to become members. In addition, the group also became more aware on the process and limitations of decision making through the direct contact with the ICNF. However, semi-institutionalization created also limitations and challenges to individual representatives and increased the exposure of the group to the dynamics of electoral cycles and political agendas.

Political acquiescence visibly increased along the decade as can be seen by the increase in legitimation from a project-driven or self-appointed informal group to one with an institutional mandate to consult the MPA management authority. In parallel, a shift was detected in the 
positioning of the management authority along this decade: at the onset of MARGov ICNF was treated by the project team as any other institutional stakeholder. ICNF participation was guaranteed by natural and social scientists with local knowledge and experience or by senior management representatives, but lack of differentiated treatment led to some institutional discomfort that progressively faded away. ICNF scientists that followed MARGov were also present in the early post-MARGov events and one of them became institutional representative in the Group of the Sea. This long-term engagement contributed the indirect acquisition of policy acumen by the group and, simultaneously, osmotic assimilation of information by managers and decision makers within ICNF.

\section{DISCUSSION}

The PMLS case study provided a basis for reflecting on the achievements of a long term collaborative process aiming towards marine sustainability. Evaluation goes beyond the usual assessment since it also reflects on lessons learned from the set-backs and failures (Zscheischler and Rogga, 2015) that occurred during a decade (2008-2017). The combination of gains in production and processing of relevant information, group member trust and capacity to work together, have contributed to the setting of a collective agenda and the production of innovative solutions, both indicative of the achievements of a community of practice (Lave and Wenger, 1991). This created actionable knowledge for fisheries management in the PMLS that can be readily mobilised when legal opportunity arises: this happened in 2018 as part of a legal obligation to translate all special territorial plans in mainland Portugal into programs by 2020 .

Collective engagement allowed the clarification of key problematic areas in the PMLS regulation, a better understanding of member positions and interests and provided an explanation why in some 
cases it was not possible to reach agreement. This permitted the shaping of boundary objects (Stange et al., 2016) as new intellectual capital that may be mobilized in the future. This capital can be used both to focus further future engagement (e.g. the 100 days rule for PMLS license renewal) and for reframing debate (e.g. on the merits and inconveniencies of specific incentives to local MPA enterprises or the links between local fisheries and tourism). Although there is greater generalized appetence for tangible outcomes, in fact, intangible outcomes provide the robustness of a process needed for collaboration sustainability. A decade of collective engagement showed that intangible outcomes - the emergence of key actors and the progression towards an outcomedriven agenda - can play a major role. In the PMLS case, although these intangible outcomes were key to increase the production of tangible MPA sustainability proposals, they also created e setback on the mobilization of less active members. Moreover, although legitimation was important for the institutionalization and recognition of the process, it may also have had a negative effect on the flexibility and adaptability of the process.

Both the above empirical findings should be taken under consideration in the design of future collaboration processes and deserve additional scrutiny through comparison with other long-term studies and theoretical exploration of how to negotiate such tensions. On the wider context of MPA management and governance, the clarification of bundles of rights under dispute or negotiation (Schleger and Ostrom, 1992) is important to focus conflict and to promote joint deliberation. In this respect, the recent classification system for MPA effectiveness based explicitly on regulations (Horta e Costa et al., 2016) may prove an important tool to inform collaborative MPA engagement and make the reasons of disagreements more explicit. Such instruments can help to enhance ecological literacy and clarify the understanding of various stakeholders on concepts such as vulnerability, resilience and risk and thus allow a refinement in the joint definition of sustainability (Linke and Brukmeier, 2015; Stratoudakis et al., 2015b). 
The capacity to reach an agreement on the modification of alienation rights within the MPA, demonstrates that collective action under collaborative governance may deliver important negotiated outcomes, well beyond the compilation of individual wish-lists or joint noncommittal declarations (Bodin, 2017). This agreement managed to address a legitimate concern of the local community (since the long-term application of this rule could lead to the elimination of fishing in the area) without ignoring the necessity to devise new mechanisms to control fishing effort and reduce effort creeping (through the purchase of additional gear licenses from external fleets). As a result, the group proposal is both linked to process sustainability (it was reached almost 10 years after the onset of MARGov) and to MPA sustainability (since everyone agreed that local fishery should be maintained in the long run within the PMLS). Moreover, it demonstrates the power of joint deliberation in offering a solution to one of the most vexatious issues resulting from PMLS regulation, since it was a departure from the individual stakeholder positions.

Overall, considering this decade of collective experience we can highlight the following recommendations for sustainability practice:

a) Recognised neutrality of facilitation (both as lack of involvement in the conflict content and as independence from the power structure of participant institutions) is necessary to surpass lack of trust and other tensions that inevitably emerge during collaborative decision processes;

b) The influence of political cycles is a factor of contingency that can be anticipated, as preelectoral turbulence is almost guaranteed to recruit topics of MPA governance, especially at the local level; 
c) Some visible political acquiescence at a senior level relatively early in the engagement process is likely to facilitate information flow within the administration and maintain mobilisation and participation of stakeholders;

d) Some visible improvement of local environmental values is necessary to maintain confidence and legitimation of spatially-explicit management rules.

Though such an engagement reveals to be more demanding and challenging than traditional participatory processes, it is also more enriching for continuity and assurance of sustainability in the long run. Clearly, irrespective of future developments, the ones really committed to collective engagement developed social and intellectual capital that will certainly inform future action and interactions. Adequate implementation of transdisciplinarity is a demanding challenge though, if difficulties are overcome, it becomes a valuable tool for facing complexity in collective actions for managing the commons. Finally, a word on transdisciplinarity as a personal practice and experience: jointly reflecting on the years of collective engagement in order to perform an evaluation of the case study and write this report (Mode 1 transdisciplinarity according to Scholz and Steiner, 2015a), proved an immensely satisfying and simultaneously utterly frustrating experience. Discussions were fruitful and enriching and the presence of an external boundary scientist provided a different equilibrium and obliged additional angles of reflectivity. However, despite the predisposition of all to participate and meet in the agora (Pohl et al., 2010), disciplinary mind-frames and languages are difficult to overcome and can easily create misunderstandings and narrow the common space - transdisciplinary engagement is hard work with no guaranteed return. Similar were the feelings along the decade of collective engagement in the PMLS (Mode 2 transdisciplinary according to Scholz and Steiner, 2015a): many were the meetings to end in a tired and frustrated mood, questioning whether all this was worth it, only to have a next meeting where some unforeseen development of solution or approximation would 
provide reasons for satisfaction and strengthen the commitment to continue. And then, suddenly, 10 years had gone by.

\section{ACKNOWLEDGEMENTS}

An earlier version of this work was presented to the 2017 European Conference of planning AESOP 2017 (Lisboa, 11-14/7/2017) - Spaces of dialogue for places of dignity: fostering the European dimension of planning. We thank all people that have contributed to collective engagement related to PMLS since the onset of the project MARGov in 2008 and the funding authorities of MARGov (Fundação Calouste Gulbenkian, Programa Gulbenkian Ambiente and Oceanário de Lisboa) and MAIA (EU, INTERREG : www.maia-network.org). We also want to thank all group members and assistants of the facilitation team that have been part of this long adventure, and the Municipality of Sesimbra for all the logistic support and its, recently and prematurely departed, Mayor Augusto Polvora for his frank collaboration, constructive criticism and inspiring and contaminating energy. YS wants to acknowledge Carlos Costa Monteiro and Miguel Neves dos Santos for their support to initiate research in this thematic area and the project OCTOPARQUE (funded by the Oceanário de Lisboa) for supporting transport costs and related engagement in recent years. LV thanks the Foundation for Sciences and Technology for having partially funded this research through the support to MARE - Strategic Program UID/MAR/04292/2013. Finally, we want to acknowledge the important contribution of the two referees that helped us to revise considerably the original submission.

\section{REFERENCES}


Abecassis D, Afonso P, Erzini K (2014) Combining multispecies home range and distribution models aids assessment of MPA effectiveness. Marine Ecology Progress Series 513:155-169 DOI:10.3354/meps10987

Ansell C, Gash A (2008) Collaborative governance in theory and practice. Journal of Public Administration Research and Theory 18:543-571 DOI:10.1093/jopart/mum032

Batista MI, Henriques S, Pais MP, Cabral HN (2014) Assessment of cumulative human pressures in a coastal area: integrating information for MPA planning and management. Ocean and Coastal Management 102: 248-257 DOI:10.1016/j.oceanman.2014.09.020

Batista MI, Horta e Costa B, Gonçalves L, Henriques M, Erzini K, Caselle JE, Gonçalves EJ, Cabral HN (2015) Assessment of catches, landings and fishing effort as useful tools for MPA management. Fisheries Research 172:197-208 DOI:10.1016/j.fishres.2015.07.020

Bennett NJ, Govan H, Satterfield T (2015) Ocean grabbing. Marine Policy 57: 61-68 DOI:10.1016/j.marpol.2015.05.026

Bennett NJ, Roth R, Klain SC, Chan K, Christie P, Clark DA, Cullman G, Curran D, Durbin TJ, Epstein G, Greenberg A, Nelson MP, Sandlos J, Stedman R, Teel TL, Thomas R, Veríssimo D, Wyborn C (2017) Conservation social science: understanding and integrating human dimensions to improve conservation. Biological Conservation 205:93-108 DOI:

10.1016/j.biocon.2016.10.006

Bingham LB, Fairman D, Fiorino DJ, O'Leary R (2003) Fulfilling the Promise of Environmental Conflict Resolution. In The Promise and Performance of Environmental ConflictResolution, ed. O'Leary and Bingham. Washington, DC: Resources for the Future. Pp. 329-351.

Bodin O (2017) Collaborative environmental governance: achieving collective action in socialecological systems. Science 357 (6352), eaan1114 
Boschetti F, Cvitanovic C, Fleming A, Fulton E (2016) A call for empirically based guidelines for building trust among stakeholders in environmental sustainability projects. Sustainability Science DOI:10.1007/s11625-016-0382-4

Bryson JM, Crosby BC (1992) Leadership for the common good. Tackling problems in a sharedpower world. San Francisco, Jossey-Bass

Carneiro G (2011) The Luiz Saldanha marine park: an overview of conflicting perceptions. Conservation and Society 9:325-333 DOI:10.4103/0972-4923.92149

Cunha AH, Erzini K, Serrão E, Gonçalves E, Borges R, Henriques M, Henriques V, Guerra M, Duarte C, Marbá N, Fonseca M (2014) BIOMARES, a LIFE Project to restore and manage the biodiversity of Prof Luiz Saldanha Marine Park. Journal of Coastal Conservation 18:643-655 DOI:10.1007/s11852-014-0336-x

Day D (1997) Citizen participation in the planning process: an essentially contested concept? Journal of Planning Literature 11:421-434

Dietz T, Ostrom E, Stern PC (2003) The struggle to govern the commons. Science 302:1907-1912

Dryzek JS (2000) Deliberative democracy and beyond. Liberals, critics, contestations. Cambridge University Press, Cambridge, England

Edwards VM, Steins N (1998) Developing an analytical framework for multiple-use commons. Journal of Theoretical Politics 10(3):347-383

Fung A, Wright EO (2001) Deepening democracy: innovations in empowered participatory governance. Politics and Society 29:5-41

Gray B, Wood DJ (1991) Collaborative alliances: moving from practice to theory. Journal of Applied Behavioral Science 27( 2): 3-22

Healey P (1997) Collaborative Planning. Shaping Places in Fragmented Societies. MacMillan Press 
Henriques V, Guerra MT, Mendes B, Gaudêncio MJ, Fonseca P (2015) Benthic habitat mapping in a Portuguese marine protected Area using EUNIS: an integrated approach. Journal of Sea Research 100:77-90 DOI:10.1016/j.seares.2014.10.007

Hessels LK, van Lente H (2008) Re-thinking new knowledge production: A literature review and a research agenda. Research Policy 37:740-760 DOI: 10.1016/j.respol.2008.01.008

Holzer JM, Carmon N, Orenstein DE (2018) A methodology for evaluating transdisciplinary research on coupled socio-ecological systems. Ecological Indicators 85: 808-819 DOI:10.10116/j.ecol.ind.2017.10.074

Horta e Costa B, Claudet J, Franco G, Erzini K, Caro A, Gonçalves EJ (2016) A regulation-based classification system for Marine Protected Areas (MPAs). Marine Policy 72:192-198 DOI:10.1016/j.marpol.2016.06.021

Huxham, C (1996) Collaboration and Collaborative Advantage. In Creating Collaborative Advantage, ed. Huxham, Thousand Oaks, CA: Sage. pp. 1-18.

Innes J, Broher DE (1999) Consensus building and complex adaptive systems. Journal of the American Planning Association 65:412-23. DOI: 10.1080/01944369908976071

Innes JE, Booher DE (2004) Reframing public participation: strategies for the 21st century. Planning Theory and Practice, 5(4): 419-436, DOI: 10.1080/1464935042000293170

Jacobsen RB, Wilson DC, Ramirez-Monsalve P (2012) Empowerment and regulation - dilemmas in participatory fisheries science. Fish and Fisheries 13:291-302 DOI:101111/j.1467-

29799.2011.00434.x

Lake RW (Ed.) (1987) Resolving locational conflict. Center for Urban Policy Research, Rutgers - The State University of New Jersey, USA. 
Lang DJ, Wiek A, Bergmann M, Stauffacher M, Martens P, Moll P, Swilling M, Thomas CJ (2012) Transdisciplinarity research in sustainability science: practice, principles and challenges. Sustainability Science 7(Suppl 1):25-43 DOI: 10.1007/s11625-011-0149-x

Lave J, Wenger E (1991) Situated learning: legitimate peripheral participation. Cambridge University Press, Cambridge

Linke S, Bruckmeier K (2015) Co-management in fisheries - experience and changing approaches in Europe. Ocean and Coastal Management 104:170-181

DOI:10.1016/j.oceancoaman.2014.11.017

Linke S, Jentoft S (2016) Ideals, realities and paradoxes of stakeholder participation in EU fisheries governance. Environmental Sociology 2(2):144-154 DOI:10.1080/23251042.2016.1155792

Marshall N, Adger N, Attwood S Brown C, Crissman C, Cvitanovic C, De Young C, Gooch M, James C, Jessen S, Johnson D, Marshall P, Park S, Wachenfeld D, Wrigley D (2017) Empirically derived guidance for social scientists to influence environmental policy. PLOS1 12(3):e0171950

Pohl C, Rist S, Zimmermann A, Fry P, Gurung GS, Schneider F, Speranza Cl, Kiteme B, Boillat S, Serrano E, Hadron GH, Wiesmann U (2010) Researchers' roles in knowledge co-production: experience from sustainability research in Kenya, Switzerland, Bolivia and Nepal. Science and Public Policy 37(4):267-281 DOI:10.3152/030234210X496628

Reed MS (2008) Stakeholder participation for environmental management: a literature review. Biological Conservation 141:2417-2431 DOI:10.1016/j.biocon.2008.07.014

Regeer BJ, Hoes AC, Amstel-van Saane M, Caron-Flinterman F, Bunders JFG (2009) Six guiding principles for evaluating mode-2 strategies for sustainable development. American Journal of Evaluation 30 (4): 515-537

Rittel HWJ, Weber MM (1973) Dilemmas in a general theory of planning. Policy Science 4:155-169 
Roos J (2017) Practical wisdom: making and teaching the governance case for sustainability.

Journal of Cleaner Production 140:117-124 DOI:10.1016/j.clepro.2015.10.135

Schlager E, Ostrom E (1992) Property-rights regimes and natural resources: a conceptual analysis.

Land Economics 68(3):249-262

Scholz RW, Steiner G (2015a) The real type and ideal type of transdisciplinary processes: part Itheoretical foundations. Sustainability Science 10:527-544 DOI:10.1007/s11625-015-0326-

4

Scholz RW, Steiner G (2015b) The real type and ideal type of transdisciplinary processes: part IIwhat constraints and obstacles do we meet in practice? Sustainability Science 10: 653-671 DOI:10.1007/s11625-015-0327-3

Spangenberg JH (2011) Sustainability science: a review, an analysis and some empirical lessons. Environmental Conservation 38(3):275-287 DOI:10.1017/S0376892911000270

Stange K, van Leeuwen J, van Tatenhove J (2016) Boundary spaces, objects and activities in mixedactor knowledge production: making fishery management plans in collaboration. Maritime Studies 15:14 DOI:10.1186/s40152-016-0053-1

Stratoudakis Y, Azevedo M, Farias I, Macedo C, Moura T, Polvora MJ, Rosa C, Figueiredo I (2015a) Benchmarking for data-limited fishery systems to support collaborative focus for solutions. Fisheries Research 171:122-129 DOI:10.1016/j.fishres.2014.10.001

Stratoudakis Y, Fernández F, Henriques M, Martins J, Martins R (2105b) Situação ecológica, socioeconómica e de governança após a implementação do primeiro plano de ordenamento no Parque marinho Professor Luiz Saldanha (Arrábida, Portugal): I - informações e opiniões dos pescadores. Journal of Integrated Coastal Zone Management 15(2):153-166

DOI:10.5894/rgci571 
Stratoudakis Y, Fernández F, Henriques M, Martins J, Martins R (2105c) Situação ecológica, socioeconómica e de governança após a implementação do primeiro plano de ordenamento no Parque marinho Professor Luiz Saldanha (Arrábida, Portugal): Il - percepções de utentes. Journal of Integrated Coastal Zone Management 15(2):167-176 DOI:10.5894/rgci572

Stratoudakis Y, Fernández F, Martins R, Carneiro M, Santos MN (2015d) Fisher participation in data collection and advice provision within an MPA. In Vasconcelos L, Silva F (Eds) The power of Dialogue: Sustainability in the $21^{\text {st }}$ century, MARGov Project, pp 182-203

Thompson MA, Perry JK, Miller T K (2008) Linking collaboration processes and outcomes: foundations for advancing empirical theory. In G. Bingham \& R. O'Leary (Eds) Big ideas in collaborative public management. Armonk, NY: M. E. Sharpe, pp 97-120

Thompson MA, Owen S, Lindsay JM, Leonard GS, Cronin SJ (2017) Scientist and stakeholder perspectives of transdisciplinary research: early attitudes, expectations and tensions. Environmental Science and Policy 74:30-39 DOI:10.1016/j.env.sci.2017.04.006

Vasconcelos L (2005) Deliberative forums in new governance - overcoming ingrained myths. AESOP Congress “The Dream of a greater Europe”, 13-17/7/2005, Vienna, Austria.

Vasconcelos L, Caser U, Ramos Pereira MJ, Gonçalves G, Sá R (2012) MARGov - Building social sustainability. Journal of Coastal Conservation 16:523-530 DOI:10.1007/s11852-012-0189-0

Vasconcelos L, Caser U, Silva F, Ramos Pereira MJ, Sá R, Coelho M, Ferreira JC (2015) Governance: collaborative governance through the eco-social dialogue. In Vasconcelos L, Silva F (eds) The power of Dialogue: Sustainability in the $21^{\text {st }}$ century, MARGov Project, pp 33-54

Wittmayer JM, Schapke N (2014) Action, research and participation: roles of researchers in sustainability transitions. Sustainability Science 9:483-496 DOI:10.1007/s11625-014-0258-4 
Zscheischler J, Rogga S (2015) Transdisciplinarity in land use science - A review of concepts,

empirical findings and current practices. Futures 65: 28-44

DOI:10.1016/j.futures.2014.11.005 
Table 1: Elements of participation and trend criteria to evaluate change between phases in longterm engagement processes (adapted from Vasconcelos, 2005).

\begin{tabular}{|c|c|}
\hline Element of Participation & Trend Criterion \\
\hline 1. Political acquiescence - to guarantee the legitimacy of decisions & Legitimation \\
\hline $\begin{array}{l}\text { 2.Professional facilitator - to structure and conduct the participatory } \\
\text { process assuring neutral ground }\end{array}$ & Neutrality \\
\hline $\begin{array}{l}\text { 3.Space adequacy for participatory sessions - with growth in controversy, } \\
\text { the greater the care in choosing independent location for the meetings to } \\
\text { promote space appropriation and familiarity (i.e., meeting space becoming } \\
\text { a comfortable environment to for participants) }\end{array}$ & Space significance \\
\hline $\begin{array}{l}\text { 4A. Agenda - thematic scope of the agenda and degree of preparation } \\
\text { required of participants prior to meetings }\end{array}$ & Level of challenge \\
\hline $\begin{array}{l}\text { 4B. Issue Approach - the greatest the complexity the more attention is } \\
\text { needed to desegregate the issue in manageable components to be } \\
\text { addressed by the participants }\end{array}$ & $\begin{array}{l}\text { Recognition and } \\
\text { management of complexity }\end{array}$ \\
\hline $\begin{array}{l}\text { 4C. Problem Translation - consolidation of problem definition and interest } \\
\text { sharing (i.e., level of problem framing and interest expression - see also } \\
\text { Stratoudakis et al., 2015a) }\end{array}$ & $\begin{array}{l}\text { Problem } \\
\text { definition/interests }\end{array}$ \\
\hline $\begin{array}{l}\text { 5.Actors Involvement - evolution of the level and roles assumed by actors } \\
\text { participating in the process }\end{array}$ & Level of involvement \\
\hline $\begin{array}{l}\text { 6.Information Mode - production, circulation and processing of } \\
\text { information feeding collective work }\end{array}$ & Information flux \\
\hline $\begin{array}{l}\text { 7.Process Dynamics - capacity to address unexpected actions or events } \\
\text { (internal of external to the system) }\end{array}$ & $\begin{array}{l}\text { Resilience/Capacity of } \\
\text { adaptation }\end{array}$ \\
\hline $\begin{array}{l}\text { 8. Registration of contributions - development of registration base for } \\
\text { collective action (i.e., minutes of meetings, reports, individual and } \\
\text { collective position papers, etc.) }\end{array}$ & Group memory \\
\hline
\end{tabular}




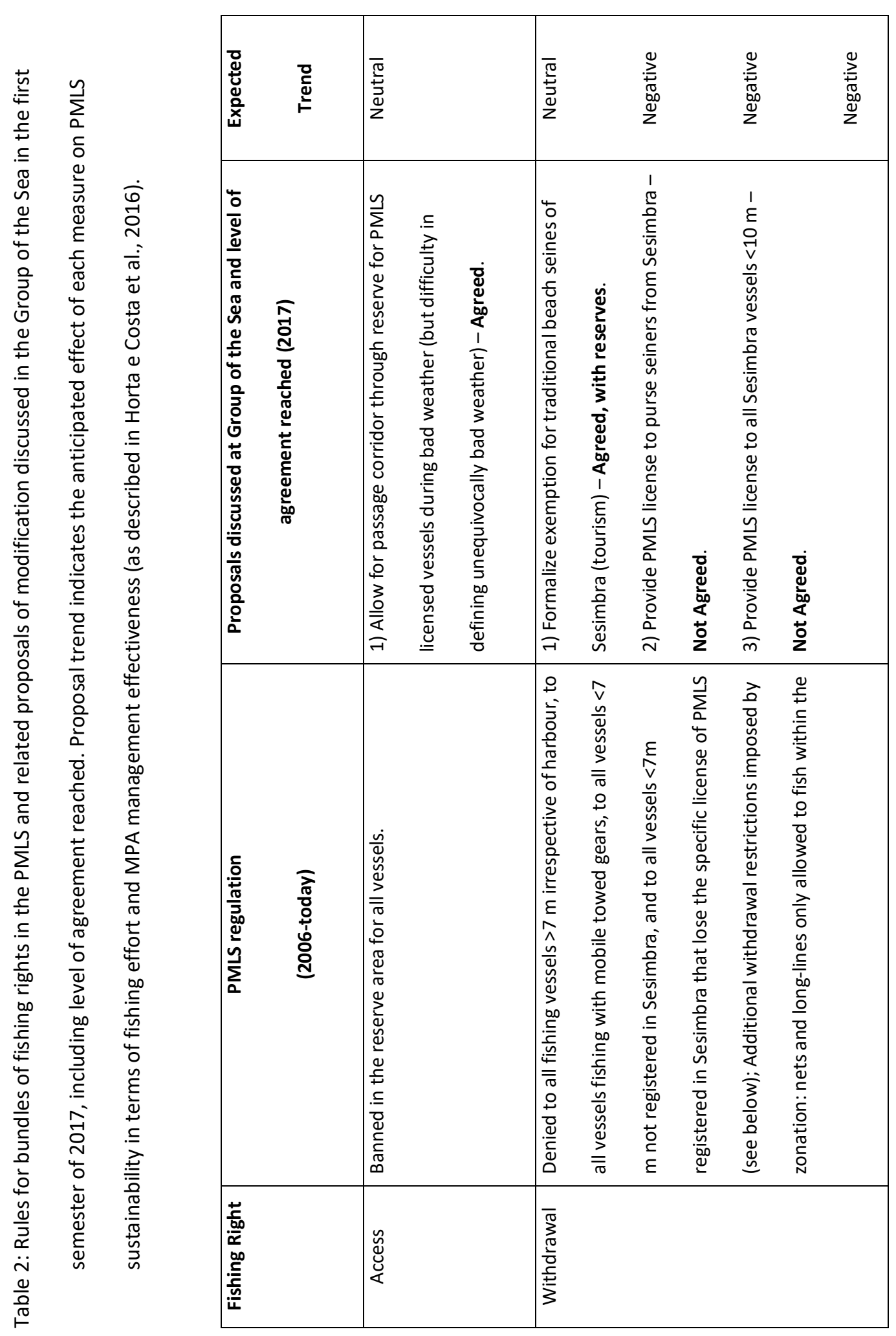

$\stackrel{n}{m}$ 


\begin{tabular}{|c|c|c|c|c|c|c|c|c|c|c|c|c|c|c|c|c|c|}
\hline & 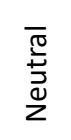 & & & 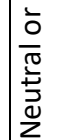 & 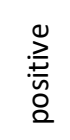 & & & 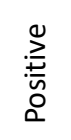 & & & 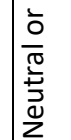 & 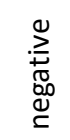 & & $\begin{array}{l}\overline{0} \\
\frac{\sqrt{5}}{5} \\
\frac{0}{2}\end{array}$ & & $\begin{array}{l}\frac{\overline{0}}{\pi} \\
\frac{\pi}{5} \\
\frac{0}{2}\end{array}$ & 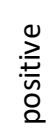 \\
\hline 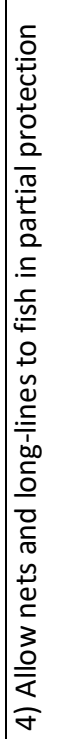 & 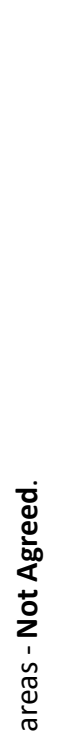 & 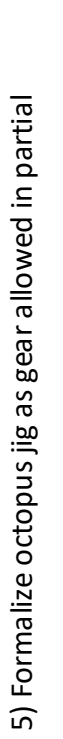 & 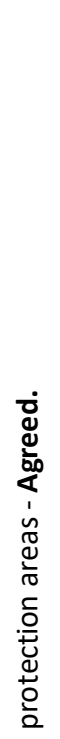 & 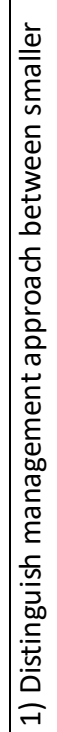 & 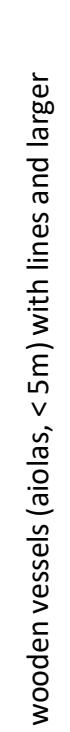 & 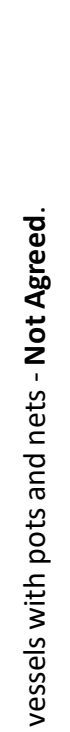 & 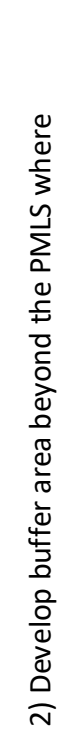 & 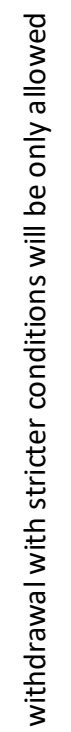 & 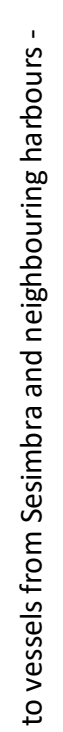 & 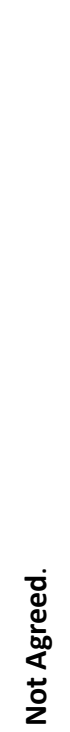 & 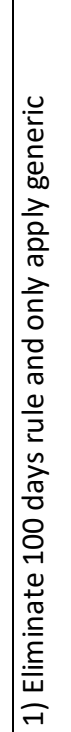 & 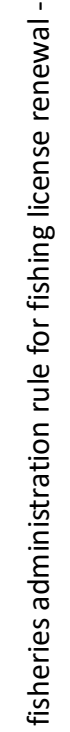 & 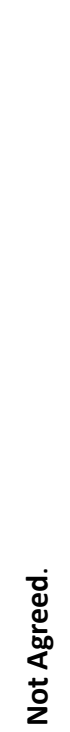 & 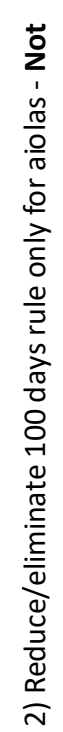 & 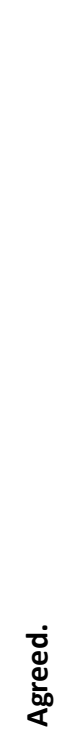 & & \\
\hline 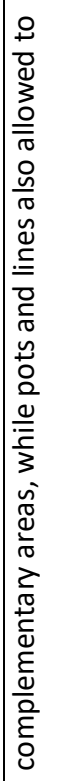 & 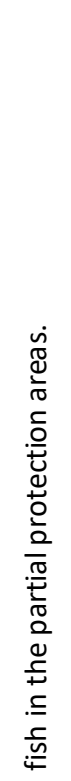 & & & 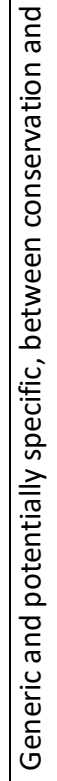 & 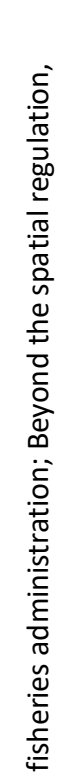 & 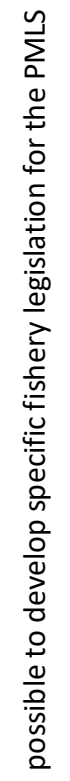 & 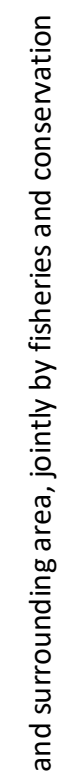 & 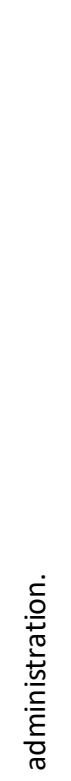 & & & 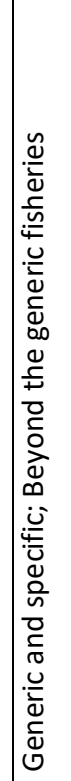 & 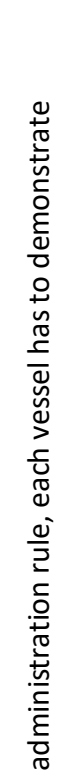 & 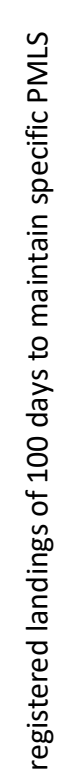 & 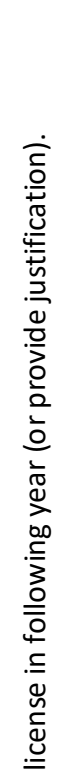 & & & \\
\hline & & & & 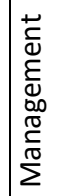 & & & & & & & 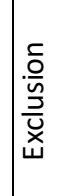 & & & & & & \\
\hline
\end{tabular}

m 


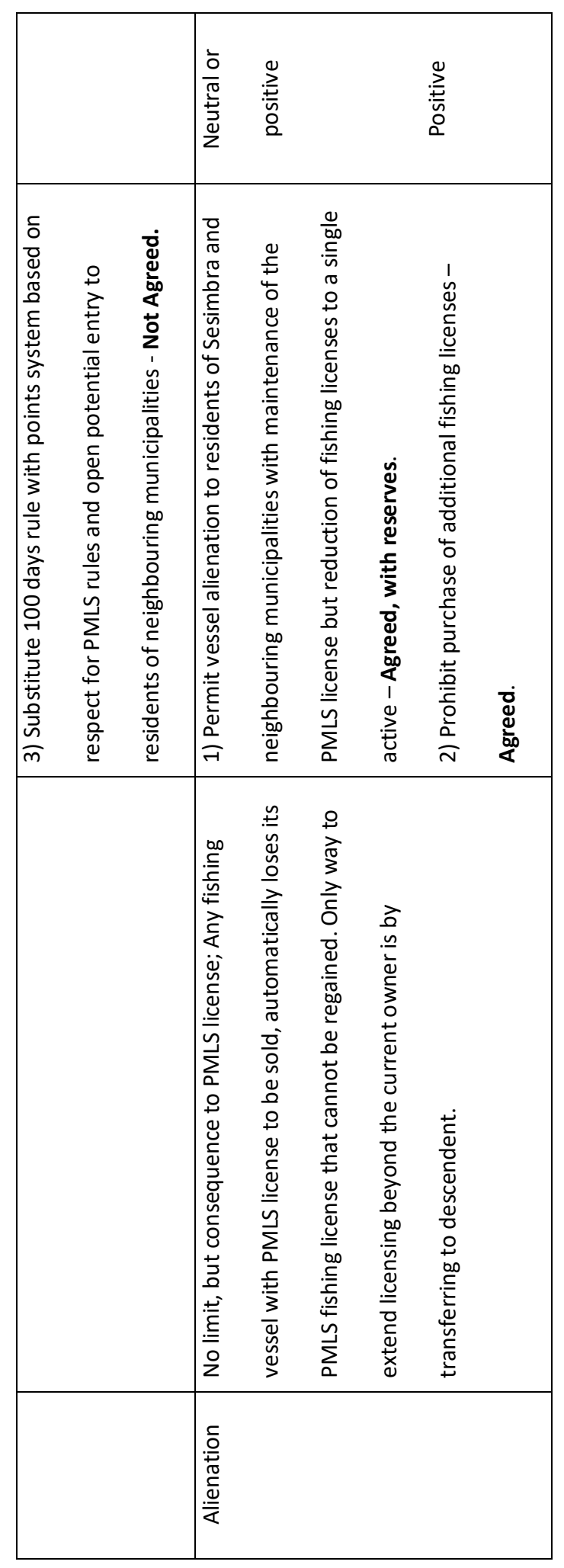

$\hat{m}$ 


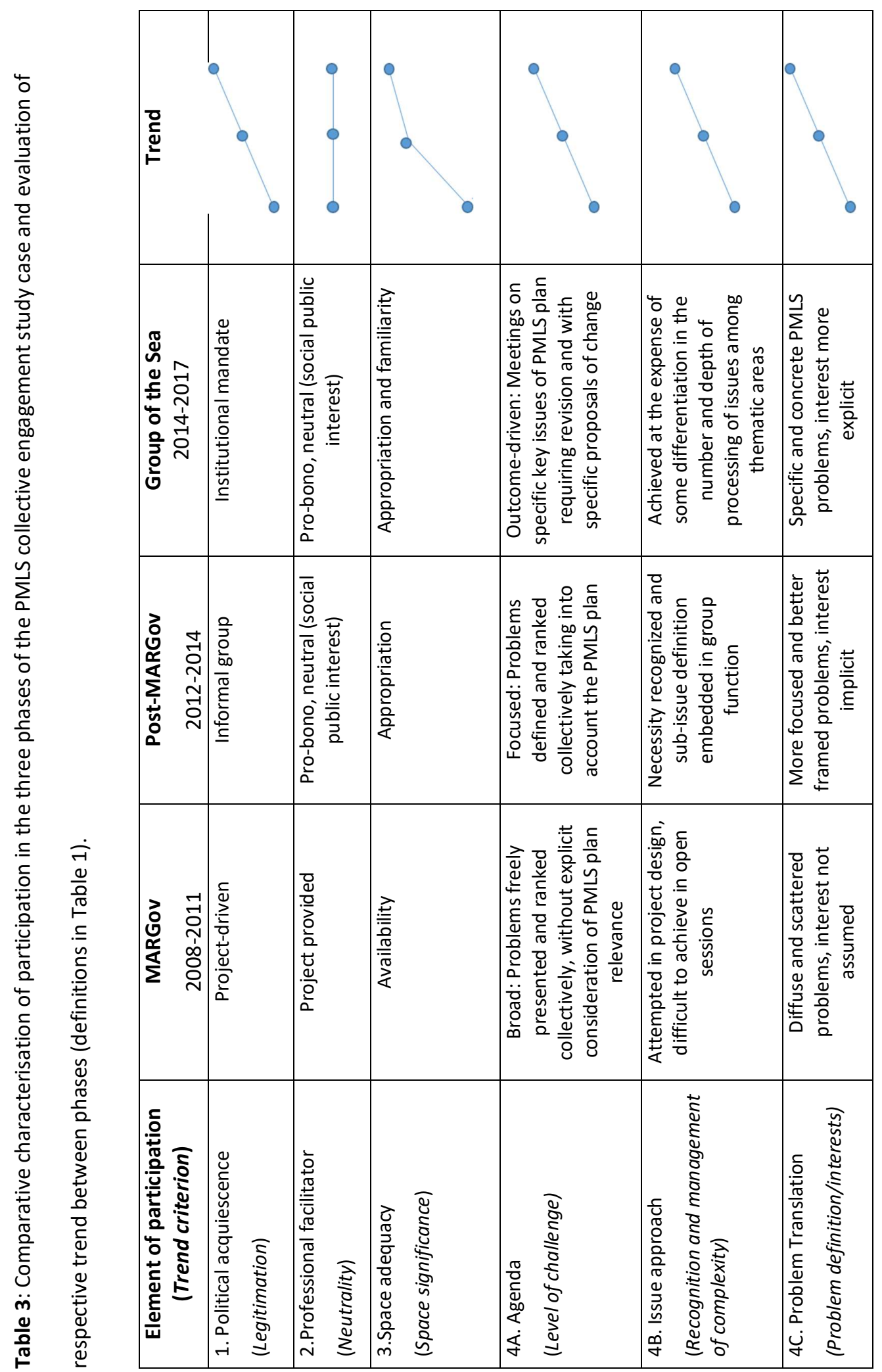




\begin{tabular}{|c|c|c|c|}
\hline$\xi$ & 9 & 0 & $\rho$ \\
\hline 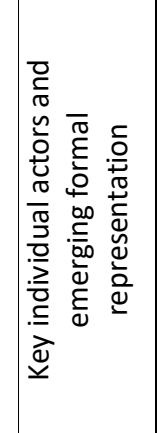 & 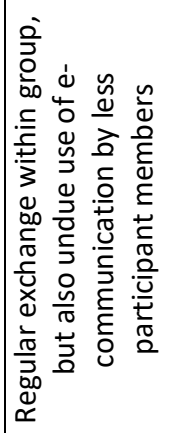 & 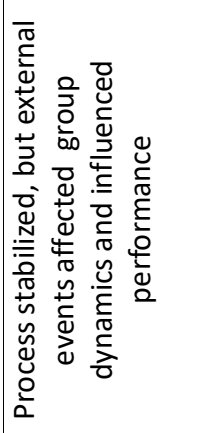 & 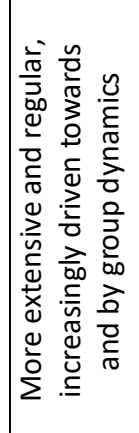 \\
\hline 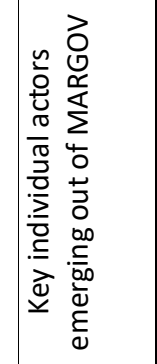 & 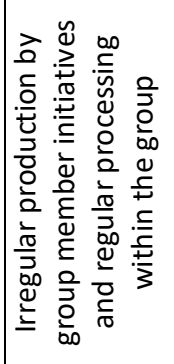 & 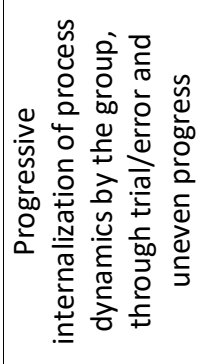 & 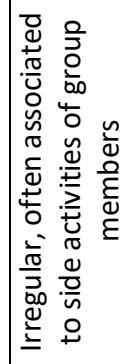 \\
\hline 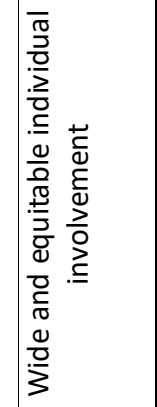 & 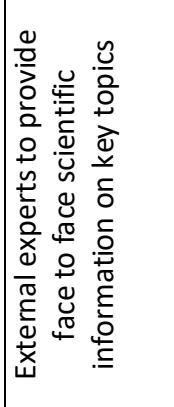 & 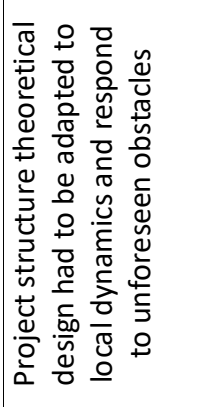 & 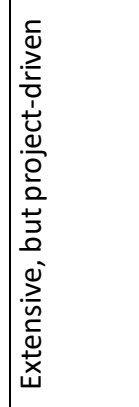 \\
\hline 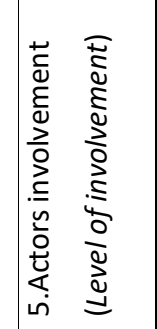 & 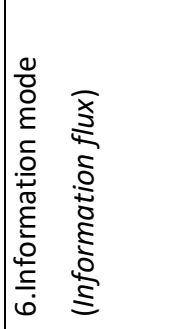 & 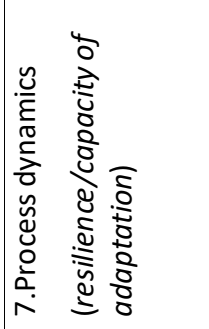 & 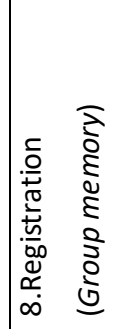 \\
\hline
\end{tabular}


Table 4: Tangible and intangible outcomes by type of capital and phase of collective engagement in the governance of the PMLS

\begin{tabular}{|c|c|c|c|c|}
\hline Outcomes & Capital & $\begin{array}{l}\text { MARGov } \\
\text { 2008-2011 }\end{array}$ & $\begin{array}{c}\text { post-MARGov } \\
\text { 2012-2014 }\end{array}$ & $\begin{array}{c}\text { Group of the SEA } \\
2014-2017\end{array}$ \\
\hline \multirow[t]{3}{*}{$\begin{array}{l}\frac{0}{0} \\
\frac{0}{00} \\
\frac{1}{\sqrt{0}} \\
\vdash\end{array}$} & Intellectual & $\begin{array}{l}\text { Thematic } \\
\text { organization, } \\
\text { technical inputs and } \\
\text { public discussion on } \\
\text { key problematic } \\
\text { areas (e.g. } \\
\text { surveillance, } \\
\text { pollution, coastal } \\
\text { erosion) } \\
\text { Sharing of different } \\
\text { types of knowledge, } \\
\text { with more expression } \\
\text { of conceptual than of } \\
\text { actionable } \\
\text { knowledge }\end{array}$ & $\begin{array}{l}\text { International contacts } \\
\text { and dialogue (MAIA } \\
\text { project, Corunha } \\
\text { conference, Cedeira } \\
\text { visit) } \\
\text { Publications on the } \\
\text { social-ecological } \\
\text { system and its } \\
\text { governance }\end{array}$ & $\begin{array}{l}\text { International } \\
\text { contacts follow-up } \\
\text { and dialogue (link } \\
\text { with Cofradia Burela) } \\
\text { Proposal to bring } \\
\text { ecological research } \\
\text { groups and results } \\
\text { closer to group } \\
\text { Utilization and } \\
\text { scrutiny of } \\
\text { publications to } \\
\text { respond to PMLS } \\
\text { regulation review } \\
\text { Development of a } \\
\text { Final Joint Document } \\
\text { Consolidation of } \\
\text { actionable } \\
\text { knowledge } \\
\text { (negotiated mutually } \\
\text { agreed rules) }\end{array}$ \\
\hline & Social & $\begin{array}{l}\text { Emergence of key } \\
\text { stakeholders }\end{array}$ & $\begin{array}{l}\text { Voluntary group } \\
\text { formation with } \\
\text { intermittent NGO } \\
\text { involvement } \\
\text { External spinoff (e.g. } \\
\text { fisherman basket) }\end{array}$ & $\begin{array}{l}\text { Stabilization and } \\
\text { consolidation of } \\
\text { NGO involvement }\end{array}$ \\
\hline & Political & $\begin{array}{l}\text { Proposal of } \\
\text { governance structure } \\
\text { approximating co- } \\
\text { management }\end{array}$ & $\begin{array}{l}\text { Compilation of } \\
\text { recommendations for } \\
\text { modification of } \\
\text { collective-choice rules }\end{array}$ & $\begin{array}{l}\text { Formal integration } \\
\text { within Strategic } \\
\text { Council }\end{array}$ \\
\hline
\end{tabular}




\begin{tabular}{|c|c|c|c|c|}
\hline & & & $\begin{array}{l}\text { Proposal for creation } \\
\text { of different } \\
\text { governance framework } \\
\text { for operational rules } \\
\text { (adaptive } \\
\text { management) }\end{array}$ & $\begin{array}{l}\text { Requests of other } \\
\text { stakeholder groups } \\
\text { to become members } \\
\text { or to be heard }\end{array}$ \\
\hline Outcomes & Capital & $\begin{array}{l}\text { MARGov } \\
\text { 2008-2011 }\end{array}$ & $\begin{array}{c}\text { post-MARGov } \\
2012-2014\end{array}$ & $\begin{array}{c}\text { Group of the SEA } \\
2014-2017\end{array}$ \\
\hline \multirow{3}{*}{ 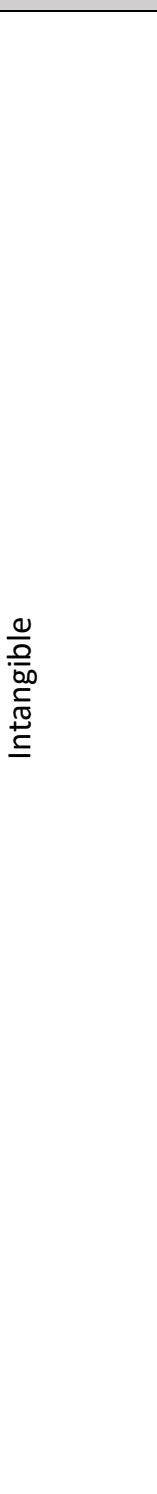 } & Intellectual & $\begin{array}{l}\text { Exhaustive public } \\
\text { presentation of } \\
\text { concerns, problems, } \\
\text { doubts, } \\
\text { recriminations and } \\
\text { conflicts }\end{array}$ & $\begin{array}{l}\text { Conceptual knowledge } \\
\text { consolidation but with } \\
\text { limited success to } \\
\text { bring ecological } \\
\text { research groups and } \\
\text { results closer to } \\
\text { stakeholders }\end{array}$ & $\begin{array}{l}\text { Emergence of } \\
\text { boundary objects } \\
\text { from actions and } \\
\text { interactions in the } \\
\text { agora space }\end{array}$ \\
\hline & Social & $\begin{array}{l}\text { Strengthening of } \\
\text { local institutions and } \\
\text { empowerment of } \\
\text { more fragile } \\
\text { stakeholders } \\
\text { Learning of process } \\
\text { rules } \\
\text { Initiation of trust- } \\
\text { building } \\
\text { Gradual increase of } \\
\text { mutual respect }\end{array}$ & $\begin{array}{l}\text { New forms of } \\
\text { collaboration } \\
\text { Strengthening of } \\
\text { networks } \\
\text { Personal bonds of } \\
\text { individuals with long } \\
\text { term participation } \\
\text { Increased } \\
\text { consolidation of } \\
\text { mutual understanding } \\
\text { and trust among } \\
\text { stakeholders }\end{array}$ & $\begin{array}{l}\text { Growing maturity } \\
\text { and responsibility of } \\
\text { stakeholders in the } \\
\text { negotiation } \\
\text { Limited capacity to } \\
\text { attract/commit } \\
\text { some stakeholders } \\
\text { Incapacity to reach } \\
\text { agreement on } \\
\text { publication of joint } \\
\text { document }\end{array}$ \\
\hline & Political & $\begin{array}{l}\text { (Some) } \\
\text { disillusionment due } \\
\text { to unfounded } \\
\text { expectations of } \\
\text { direct influence to } \\
\text { modify rules in the } \\
\text { short term } \\
\text { Emergence of } \\
\text { preliminary collective } \\
\text { discourse }\end{array}$ & $\begin{array}{l}\text { Group gaining some } \\
\text { external recognition } \\
\text { Consolidation of the } \\
\text { collective discourse }\end{array}$ & $\begin{array}{l}\text { Policy acumen } \\
\text { through direct } \\
\text { communication with } \\
\text { PMLS management } \\
\text { authority } \\
\text { Consolidation of the } \\
\text { recognition of key } \\
\text { intervention areas } \\
\text { (fishing) }\end{array}$ \\
\hline
\end{tabular}

